\title{
A REVIEW OF THE ARTICLE “NEW FINDINGS OF CASE-BEARING MOTH SPECIES OF GONIODOMA AND COLEOPHORA GENERA FROM THE BALKANS (LEPIDOPTERA: COLEOPHORIDAE)" BY RICHTER \& PASTORÁLIS (2015)
}

\section{Danijela Gumhalter}

Azuritweg 2, 70619 Stuttgart, Germany (e-mail: danijela.gumhalter@gmail.com)

Gumhalter, D.: A review of the article "New findings of case-bearing moth species of Goniodoma and Coleophora genera from the Balkans (Lepidoptera: Coleophoridae)" by Richter \& Pastorális (2015). Nat. Croat. Vol. 28, No. 1., 181-183, Zagreb, 2019.

In 2015 a paper describing new findings of micromoth species from the genera Goniodoma and Coleophora from some Balkan countries (Croatia, Montenegro, N. Macedonia and Bulgaria) was published (Richter \& Pastorális). Among other findings, 11 moth species were identified as new for the Balkans and 13 moth species as new for Croatia. But three of these species, all from the genus Coleophora, were previously reported for Croatia and thus do not represent new findings, either for the Balkans or for Croatia.

The two supposedly newly identified species for the Balkans are Coleophora ahenella (Heinemann, 1877) and Coleophora gallipennella (Hübner, 1796). Both species were previously reported for the fauna of Croatia, so these findings do not represent new findings for the Balkans. Also the supposedly new species for the fauna of Croatia, Coleophora bilineella (Herrich-Schäffer, 1855), was previously reported for Croatia and therefore does not represent a new species for the fauna of Croatia.

Key words: Review, Microlepidoptera, case bearing moths, Goniodoma, Coleophora, Balkan, Croatia

Gumhalter, D.: Osvrt na rad „Novi nalazi moljaca tuljčara iz roda Goniodoma i Coleophora za Balkan (Lepidoptera: Coleophoridae) “ autora Richter \& Pastorális (2015). Nat. Croat. Vol. 28, No. 1., 181-183, Zagreb, 2019.

Godine 2015. objavljen je članak (Richter \& Pastorális) u kojem su izneseni podaci o pronalascima novih vrsta mikrolepidoptera iz roda Goniodoma i Coleophora iz nekih balkanskih zemalja (Hrvatska, Crna Gora, Makedonija i Bugarska). Pored drugih pronalazaka, u radu je predstavljeno 11 vrsta novih za Balkan i 13 vrsta novih za faunu Hrvatske. Međutim, tri su vrste prethodno zabilježeno na području Hrvatske. Stoga njihovi pronalasci ne predstavljaju ni novu vrstu za Balkan, niti novu vrstu za Hrvatsku.

Dvije navodno nove vrste za Balkan su Coleophora ahenella (Heinemann, 1877) i Coleophora gallipennella (Hübner, 1796), no obje su vrste prethodno zabilježene na prostoru Hrvatske pa njihovi pronalasci ne predstavljaju nove vrste za Balkan. Usto, navodno nova vrsta za faunu Hrvatske, Coleophora bilineella (Herrich-Schäffer, 1855) je također prethodno zabilježena za faunu Hrvatske i njen pronalazak ne predstavlja novu vrstu za faunu Hrvatske.

Ključne riječi: Razmatranje, mikrolepidoptera, moljci tuljčari, Goniodoma, Coleophora, Balkan, Hrvatska 
Richter \& Pastorális (2015) published in the Periodical of Hungarian Microlepidoptera a paper entitled "New findings of case-bearing moth species of Goniodoma and Coleophora genera from the Balkans (Lepidoptera: Coleophoridae)". They identified 11 moth species as new for the Balkans and 13 moth species as new for Croatia. But three of the presented species from the genus Coleophora were previously reported for Croatia and thus do not represent new findings for either the Balkans or Croatia. A look at the references of this paper reveals that no literature source concerning Microlepidoptera of Croatia was taken into account.

The species Coleophora ahenella is not new to the Balkans, for it was reported in 1909 from Dalmatia in Croatia (Galvagni).

Coleophora gallipennella is also not new to the Balkans since it was mentioned from Josipdol in the mountainous region of Croatia (AbAfi-Aigner et al., 1896; MANN, 1867).

The species Coleophora bilineella is not new to the fauna of Croatia. In Croatia it is distributed in the area of Josipdol (MAnN, 1867; Abafi-Aigner et al., 1896), Rijeka (Abafi-Aigner et al., 1896) and Split (Rebel, 1891).

According to Fauna Europaea, it is true, none of these species are present in the fauna of Croatia.

Coleophora ahenella is reported from Austria, Belgium, Britain, Czech Republic, the Danish mainland, Estonia, Finland, the French mainland, Germany, Hungary, the Italian mainland, Latvia, Lithuania, the Norwegian mainland, Poland, the Portuguese mainland, Romania, Slovakia, Sweden, Switzerland and the Netherlands.

Coleophora bilineella is reported from Austria, Corsica, Cyprus, the French mainland, the Greek mainland, Hungary, the Italian mainland, Kriti (Crete), the Near East, North Africa, the Portuguese mainland, Romania, Sardinia and the Spanish mainland.

Coleophora gallipennella is reported from Austria, Belgium, Czech Republic, the Danish mainland, East Palaearctic, Estonia, Finland, the French mainland, Germany, Hungary, the Italian mainland, Latvia, Lithuania, Near East, the Norwegian mainland, Poland, Romania, Slovakia, South European Russia, Sweden and Switzerland.

However, since the presence of all three species was not reconfirmed in any newer survey, the confirmation of the occurrence of Coleophora ahenella, Coleophora bilineella and Coleophora gallipennella in Croatia published together with other findings by Richter \& PAstorális in 2015 is an important contribution to the knowledge of Balkan and Croatian fauna. 


\section{REFERENCES}

Abafi-Aigner, L., Pavel, J. \& Uhryk, F., 1896: Fauna Regni Hungariae. Lepidoptera. Regia Societas Scientiarum Naturalium Hungarica, Budapest, p. 73.

Baldizzone, G. \& van der Wolf, H., 2013: Fauna Europaea: Coleophoridae. In: Karsholt, O. \& Nieukerken, E.J. van (eds.) Fauna Europaea: Lepidoptera, Moths. Fauna Europaea version 2017.06, https://fauna-eu.org [18.05.2019].

Galvagni, E., 1909: Die zoologische Reise des naturwissenschaftlichen Vereines nach Dalmatien im April 1906. 13. Lepidoptera. Beiträge zur Kenntnis der Lepidopterenfauna der Adriatischen Inseln. Mitteilungen des Naturwissenschaftlichen Vereins an der Universität Wien 7, p. 253.

ManN, J., 1867: Schmetterlinge gesammelt im J. 1866 um Josefsthal in der Croat. Militärgrenze. Verhandlungen der Zoologisch-Botanischen Gesellschaft Wien, p. 73.

Rebel, H., 1891: Beitrag zur Microlepidopteren-Fauna Dalmatiens. Verhandlungen der kaiserlichköniglichen zoologisch-botanischen Gesellschaft in Wien 41, 637.

Richter, I., \& PAstorális, G., 2015: New findings of case-bearing moth species of Goniodoma and Coleophora genera from the Balkans (Lepidoptera: Coleophoridae). Microlepidoptera.hu 8, $29-42$. 
